\title{
Pengembangan Model Pencegahan Anak-Anak Terminal dari Kekerasan Sosial dengan Pendekatan Berbasis Kekuatan dan Kewirausahaan Sosial
}

\author{
$\overline{\text { Hery Wibowo }}$
}

\begin{abstract}
Abstrak
Social violence is an issue that is always present throughout the life of human civilization. Social violence comes very close to human life in various domains of life. One thing to note from social violence is its potential to make children (and other young people) are victims and perpetrators of violence themselves socially. Social Welfare, actually has several approaches, perspectives and instruments to interact with issues of social violence. However, it is less often discussed in the scientific writing. This paper attempts to model the handling of violence through social welfare income and social entrepreneurship.
\end{abstract}

Key words: kekerasan sosial, pendekatan kesejahteraan, social entrepreneurship.

\section{Pendahuluan}

Kekerasan sosial merupakan isu yang sangat umum dan mudah ditemui di berbagai wilayah Indonesia. Indikator sederhananya adalah bahwa hampir setiap hari, di acara berita televisi, mudah sekali ditemukan berita tentang kekerasan, mulai dari kekerasan lingkup kecil sampai lingkup besar, mulai dari kekerasan yang melibatkan dua orang sampai ratusan orang dan lain-lain. Meskipun demikian, jika ditelaah lebih lanjut, penelitian ilmiah di Indonesia terkait kekerasan sosial masih sangat terbatas dan agak sulit dilakukan. Menurut Zoelfan (2001: 21) ada beberapa hal yang menyebabkannya:

(a) Belum adanya kompilasi data kekerasan sosial yang mencakup semua insiden di seluruh Indonesia yang disusun dengan suatu metode yang konsisten.

(b) Belum adanya ukuran keparahan insiden kekerasan sosial yang terbandingkan secara konsisten antar waktu dan antar daerah.

(c) Belum adanya suatu mekanisme untuk memperbaharui data (up date) yang relatif mudah dilakukan tetapi dengan tetap mengikuti suatu kaidah metodologis dan sumber informasi yang konsisten.

Namun demikian telaah ataupun kajian terkait kekerasan sosial, tidak seharusnya dihentikan. Justru, mengingat masih minimnya data, maka sebaiknya kajian terkait kekerasan sosial semakin ditingkatkan, baik secara kualitas maupun kuantitas. Oleh karena itu, tulisan ini akan mencoba mengupas potensi kekerasan sosial pada anak-anak warga terminal stasiun Bandung yang hampir setiap hari mereka melihat dan menyaksikan berbagai fenomena terminal mulai dari premanisme sampai pelacuran.

Terminal adalah salah satu lokasi yang sangat rentan dengan tindak kekerasan sosial, mulai dari penjambretan, pencurian, premanisme, pelecehan seksual dan lainlain. demikian pula dengan terminal angkot stasiun Bandung. Terminal ini terletak di lokasi yang sangat ramai, yaitu diapit oleh Pusat Perbelanjaan Pasar Baru, toko dan ruko 
garmen, hotel entertainment, diskotik, dan perkantoran, sehingga tingkat kesibukan dan kepadatan manusia di terminal tersebut sangatlah tinggi. Selain daripada berbagai pusat kegiatan tersebut, tepat menghimpit terminal yang terletak persis di belakang stasiun Bandung ini terdapat perumahan padat penduduk yang sangat heterogen. Berdasarkan observasi dan wawancara awal, didapat kesimpulan sementara bahwa penduduk asli mulai terdesak oleh datangnya pendatang yang banyak membuka usaha di sekitar stasiun dan terminal tersebut.

Kondisi tingkat kepadatan tersebut, akhirnya membuat anak-anak sangat sulit untuk dapat bermain dan beraktivitas dengan nyaman di rumah-rumah mereka. Sehingga, mereka akhirnya bermain di terminal. Terminal angkutan umum ini, selain diapit dengan pusat perbelajaan juga bersebelahan dengan kompleks pelacuran. Maka, secara mata telanjang saja, dapat dikatakan bahwa anak-anak yang hampir setiap hari bermain di terminal tersebut, akan mudah sekali menjadi korban kekerasan sosial dan pada gilirannya dapat tercebur dalam dunia premanisme dan pelacuran. Tinggal di antara kesemerawutan tersebut adalah seorang Bapak yang peduli terhadap pendidikan dan perkembangan kehidupan anak-anak mereka. Namun demikian, ia menyadari bahwa sungguh tidak mudah untuk memulai dan menyelesaikan misinya tersebut. Berdasarkan penuturan di muka, maka akan penulis akan mencoba:

(1) Mengembangkan model pencegahan anak-anak terminal tersebut melalui welfare approach.

(2) Mengombinasikan streght based approach dengan semangat dan model social entrepreneurship.

\section{Kekerasan Sosial}

Menurut M. Zoelfan T (2002: 1) kekerasan paling tidak dapat dikategorikan ke dalam empat golongan, yaitu kekerasan komunal, kekerasan separatis, state-community violence dan industrial relations related violence. Kajian di muka, menunjukkan bahwa di negara berkembang seperti Indonesia, potensi kekerasan sangat mungkin muncul dan berkembang. Satu hal terkait kekerasan adalah, sekecil atau sesingkat apapun kekerasan itu terjadi, kekerasan akan menimbulkan dampak. Bagi orang dewasa yang sudah cenderung memiliki pola pikir matang, dampak kekerasan dapat dieliminir sedemikan rupa. Namun demikian, bagaimanakah dampak kekerasan terhadap anak kecil? Bagaimanakah masa depan anakanak yang hidup di tengah-tengah kekerasan sosial?

Pertanyaan tersebut, tentu saja tidak mudah untuk dijawab. Walaupun secara observasi alamiah, dapat dikatakan bahwa sangat miris melihat anak-anak bermain di tengah lalulintas angkutan kota, para pedagang kaki lima yang hilir mudik berjualan, kompleks pelacuran terbuka yang dengan terang-terangan melakukan transaksi dll. Buruknya kondisi kemiskinan terhadap potensi perkembangan anak juga terlihat pada beberapa kajian dalam tulisan Ralph Dolgoff \& Donald Feldstein (2003: 3) berikut ini:

- Poverty is the best predictor of poor health outcomes for children, including mortality, activity limitations and utilization of health care (Edward L.Schor and Elizabeth G. Menaghan,)

- People who experienced financial difficulties in childhood are at greater risk 
of both low education attainment and poor health at age 23 and in adult life (Michaela Benzeval, Adrew Dilnot, Ken Judge and Jayne Taylor)

- $\quad$ Poor children are more likely to have physical and mental health problems, to suffer from stunted growth or lead poisioning, to score lower at reading, math, and vocabulary tests, and to drop out from school compared to non poor children ( Children's defense Fund).

Berdasarkan beberapa kajian di muka, maka dapat dijelaskan bahwa kemiskinan (belum ditambah lingkungan sosial yang kurang baik) dapat atau sangat berpontensi menghasilkan generasi yang beresiko. Artinya, secara sengaja, perlu dilakukan pendekatan ataupun langkahlangkah khusus bagi keluarga anak-anak yang berpotensi tergolong anak rawan.

Kekerasan sosial adalah sebuah isu yang multidimensional. Artinya, bukan isu tunggal yang berdiri sendiri. Terkait hal tersebut, ada satu pertanyaan awam yang muncul, yaitu siapakah yang berpotensi terkena dampak jangka panjang dari kekerasan sosial yang terjadi? Secara sederhana, dapat dikatakan bahwa pihak yang paling mungkin terkena dampak kekerasan sosial adalah anak. Anak, dengan segala kepolosan dan keluguannya dapat menjadi korban kekerasan sosial, baik secara fisik maupun sisi psikologisnya. Atau, disisi yang lain, anak justru dapat menjadi pengamat aktif dari kekerasan sosial untuk di kemudian hari, diduplikasi dalam konteks kehidupannya. Artinya, terdapat banyak potensi dampak negatif pada anak-anak yang berada di lingkungan kekerasan sosial tersebut.

Salah satu turunan dari dampak tersebut adalah bahwa anak berpotensi untuk masuk dalam kategori anak rawan atau children in need of special protection. Menurut Bagong (2010 :4), anak rawan sendiri pada dasarnya adalah sebuah istilah untuk menggambarkan kelompok anak-anak yang karena situasi, kondisi dan tekanan-tekanan kultur maupun struktur menyebabkan mereka belum atau tidak terpenuhi hak-haknya, dan acap kali pula dilanggar hak-haknya. Interior, rentan dan marginal adalah beberapa ciri yang umumnya diidap oleh anak-anak rawan. Potensi menjadi inferior adalah sesuatu yang sangat mungkin. Dengan segala keterbatasan mereka di berbagai bidang, sangat mungkin mereka akan merasa tidak sejajar dengan anak-anak lainnya yang memiliki fasilitas berlimpah.

Potensi rentan, lebih ke arah mudahnya mereka menjadi korban (pelampiasan) emosional orang tuanya, atau lingkungan sekitarnya. Sebagai contoh, jika situasi rumahnya sangat kecil dan tidak nyaman untuk belajar dan bermain, ditambah lagi dengan minimnya kepedulian orang tua, maka anak cenderung akan keluar rumah mencari lingkungan yang menurut mereka 'nyaman'. Pada kasus anak-anak terminal, lingkungan yang mereka pikir 'nyaman' tersebut, merupakan lingkungan yang berpotensi melahirkan dampak kekerasan sosial terhadap mereka. Praktik premanisme dan pelacuran, adalah pemandangan seharihari, sehingga anak-anak rentan menjadi korban dan selanjutnya menjadi penerus generasi pelaku kekerasan sosial.

Sudah menjadi rahasia umum bahwa masyarakat dunia maupun Indonesia, bergerak ke arah sikap individualistis. Kepadatan jadwal pekerjaan dan waktu tempuh dari rumah ke tempat aktivitas, membuat mereka tidak lagi mengenal apalagi berusaha memahami kondisi lingkungan sosial terdekat mereka. Ragam teknologi media sosial, juga semakin membuat masyarakat merasa tidak perlu melakukan kunjungan fisik ke tetangga terdekat atau lingkungan 
sosial di sekitar tempat tinggalnya. Pada akhirnya, masing-masing keluarga harus berjuang sendiri-sendiri untuk menghidupi dirinya dan mengoptimalkan tumbuhkembang putraputri mereka. Maka, sudah menjadi pemandangan wajar ketika terjadi peristiwa ada sebuah keluarga yang kelaparan tinggal di sebelah rumah yang berkecukupan. Artinya menipisnya aroma altruisme dan prososial semakin menjadi fenomena global.

Dalam teori sosiologi dinyatakan bahwa partisipasi sosial (keterlibatan dalam kehidupan bermasyarakat) semakin bergeser ke arah perhitungan 'pertukaran sosial' (social exchange) yang artinya dalam melakukan hubungan sosial, seseorang berhitung tentang manfaat langsung kepada dirinya dari hubungan tersebut. Lebih lanjut dikatakan bahwa secara sederhana, ide teori tersebut tercermin dalam peribahasa "take and give" di mana saat hendak memberi seseorang memperhitungkan terlebih dahulu imbalan apa yang akan dia dapatkan (berpikir take dulu sebelum give), dan perhitungan manfaat itu cenderung bersifat material financial sesuai salah satu karakteristik masyarakat industri yaitu 'wage economy' (ekonomi upah). Kondisi ini tentu saja sangat memprihatinkan dan berpotensi memperluas dampak dari kekerasan sosial yang sudah semakin masif (Budhi Wibhawa dkk, 2010: 9).

Berdasarkan uraian tersebut, maka wajar jika timbul kekawatiran terkait nasib anakanak yang berpotensi masuk kedalam golongan anak rawan (children in need of special protection), karena sikap sebagian masyarakat yang semakin individualistis. Cukup banyak hal yang semakin menguatkan hal ini, yaitu antara lain semakin banyaknya lingkungan perumahan kompleks yang berbentuk cluster tertutup. hal itu akan semakin memperkecil kemungkinan rasa empati dan kepedulian warga terhadap penduduk di sekitarnya. Belum lagi dominasi alat multi media dan jejaring sosial digital yang semakin membuat individu tenggelam dalam dunianya dan melupakan dunia sekitarnya. Oleh karena itu, tidak berlebihan kiranya jika tulisan ini dimaksudkan untuk menggugah kesadaran kita bersama terkait nasib anak-anak yang kurang beruntung tersebut.

\section{Dunia Terminal}

Terminal stasiun kota Bandung adalah lokasi bertemunya angkot dari berbagai jurusan seperti Dago-Stasiun, Lembang Stasiun dan lain-lain. Terminal ini terletak di Kelurahan Kebon Jeruk Kecamatan Andir Kota Bandung. Lokasi terminal diapit oleh deretan pertokoan padat, perkantoran, sekolah, Pusat Perbelanjaan Internasional Pasar Baru, Rumah Sakit Internasional Santosa, pusat hiburan dll. Sehingga, dapat dikatakan dari pagi sampai malam lingkungan tersebut ramai dengan lalulintas manusia dan kendaraan. Kepadatan tersebut diperparah dengan masih belum tertibnya para pedagang kaki lima menata dagangannya serta pengemudi angkutan umum dalam memberhentikan kendaraannya saat menunggu penumpang. Tak ayal, kemacetan lalulintas pun seringkali tidak terhindarkan. Jika diperhatikan, kondisi terminal angkot kota di Indonesia, memiliki banyak kesamaan, yaitu antara lain kepadatan lalulintas kendaraan dan manusia, fenomena pencurian/pencopetan, pedangan kaki lima dll. Sebuah penelitian yang dilakukan oleh Noor Afiyah (2006) menghasilkan kesimpulan bahwa masalah sosial yang timbul pada pemukiman sekitar pasar dan terminal Pacangan adalah masalah kriminalitas di mana banyak terjadi percurian, perampokan bahkan pembunuhan.

Kondisi terminal angkutan kota yang terletak di pelataran parkir Stasiun Bandung sangat dekat dengan lokasi pelacuran, bahkan boleh dikatakan hanya beberapa meter saja. 
Lokasi pelacuran tersebut bersatu dengan perumahan penduduk yang sangat padat dan berhimpitan dalam gang kecil satu dengan lainnya. Hal ini membuat anak-anak yang tinggal di daerah tersebut setiap hari dapat melihat, mengamati dan berinteraksi dengan para wanita tuna susila. Ini tentu saja dapat membuat anak-anak rentan mengikuti apa yang mereka saksikan sehari-hari.

Saptari (1997: 392) menyebutkan bahwa paling tidak ada tiga faktor yang mendorong seseorang menjadi pelacur. Pertama, karena keadaan ekonomi atau kondisi kemiskinan rumah tangga pelacur. Kedua, karena pandangan tentang seksualitas yang cenderung menekankan arti penting keperawanan sehingga tidak memberi kesempatan bagi perempuan yang sudah tidak perawan kecuali masuk ke dalam peran yang diciptakan untuk mereka. Ketiga, karena sistem paksaan dan kekerasan. Menilik kajian ini, tentu saja wajar jika muncul kekawatiran bahwa anak-anak di daerah terminal Stasiun Bandung akan terjerumus ke dalam hal-hal negatif (Bagong: 2010, 163).

\section{Kesejahteraan Sosial}

Kesejahteraan sosial dapat dipahami melalui definisi yang dikemukaan oleh Dolgoff (2003:3) yang menyatakan bahwa kesejahteraan sosial adalah semua atau segala intervensi sosial yang ditujukan untuk meningkatkan dan memelihara fungsi sosial umat manusia. Atau, mengacu pada pendapat Budi Wibhawa dkk (2010: 27) bahwa kesejahteraan sosial adalah keadaan antar hubungan manusia yang baik, yang kondusif bagi manusia untuk melakukan upaya memenuhi kebutuhan hidupnya secara mandiri.

Kesejahteraan sosial sebagai suatu keadaan hidup, tentu saja adalah suatu konsep kehidupan ideal yang harus diperjuangkan. Ini adalah kondisi yang hampir merupakan cita-cita setiap individu, keluarga ataupun masyarakat. Namun demikian, karena satu atau lain hal, terdapat beberapa kondisi yang berpotensi menghambat pencapaian kondisi ini. Kasus anak-anak terminal misalnya, mereka hidup dalam sebuah situasi yang berpontensi mengganggu ke-berfungsi-an sosial mereka. Terdapat banyak hal menyangkut faktorfaktor tidak sempurnanya ke-berfungsi-an sosial individu. Budhi Wibawa dkk (ibid, 13) menyatakan bahwa empat masalah dalam bidang kehidupan yang terkait langsung sebagai penyebab maupun sebagai akibat social disfunctioning, yaitu: kemisikinan, rendahnya pendidikan (kebodohan dalam artinya yang luas), rendahnya taraf kesehatan, dan buruknya pemeliharaan lingkungan.

Pada kasus anak terminal di stasiun Bandung, terdapat empat potensi tersebut, yaitu kemiskinan yang ditandai dengan perumahan yang padat dan berdesak-desakan sehingga mengakibatkan sanitasi kesehatan yang kurang sempurna. Selain itu, kemiskinan warga masyarakat sekitar terminal Stasiun Bandung juga menyebabkan sulitnya mereka memberikan pendidikan yang maksimal bagi putra-putri mereka, baik pendidikan formal maupun informal. Artinya, jika tidak ada satu pendekatan ataupun tindakan yang menyentuh mereka, bukan tidak mungkin akan terjadi masalah dalam keberfungsian sosial mereka. Dalam kondisi tumbuh kembang yang rentan dengan kekerasan sosial, sangat mungkin ke-berfungsi-an sosial mereka akan terganggu, atau dengan kata lain, sangat mungkin kemampuan mereka dalam melaksanakan fungsi sosialnya atau tugas-tugas kehidupan mereka-yang sesuai dengan nilai dan norma sosial yang berlaku- terganggu. 


\section{Pendekatan Berbasis Kekuatan}

Pendekatan berbasis kekuatan, atau sering dikenal dengan strength based approach, adalah sebuah pencerahan baru dalam memandang situasi/klien. Pendekatan lama/ tradisional sering diidentikkan dengan pendekatan yang memandang praktik pekerjaan sosial bermula dari masalah. Klien sering dilihat sebagai seseorang yang defisit ataupun memiliki masalah patologis, sehingga perlu ditingkatkan ke-berfungsi-annya. John Poulin menyatakan bahwa pendekatan berbasis kekuatan berfokus pada kekuatan klien, sumbersumber dan kemampuan mengatasi masalah. Klien dipandang sebagai orang yang mampu melakukan perubahan (John Poulin 2005: 2). Satu perubahan besar pada pendekatan ini adalah perubahan cara pandang kita terhadap klien. Berikut ini adalah beberapa prinsip yang diajarkan oleh John Poulin yang perlu dipegang dalam penerapan pendekatan berbasis kekuatan (strength based approach):

(a) Setiap individu, kelompok, keluarga dan komunitas memiliki kekuatan.

(b) Trauma, penyalahgunaan, penyakit dan perjuangan hidup mungkin menyakitkan dan menyebabkan luka, namun hal tersebut juga merupakan sebuah tantangan dan peluang.

(c) Diasumsikan bahwa kita tidak memiliki limit dari kapasitas untuk bertumbuh dan berubah, oleh sebab itu perlu sekali untuk mendengarkan aspirasi dari individu, kelompok dan masyarakat.

(d) Cara terbaik melayani klien adalah dengan berkolaborasi dengan mereka.

(e) Setiap lingkungan penuh dengan sumber-sumber.

(f) Perawatan. perhatian dan konteks merupakan hal yang penting.

Semua itu akan menjadi titik berangkat yang penting dari usaha-usaha untuk membangun aktivitas pendidikan moral anak-anak terminal dalam upaya pencegahan agar tidak masuk ke dalam dunia hitam. Artinya, anak-anak terminal, walaupun sebagian dari keluarga mereka kurang beruntung secara ekonomi haruslah dianggap sebagai anak yang mempunyai potensi kecerdasan dan tumbuh kembang optimal. Selain itu, segala keterbatasan kehidupan mereka akan dipandang sebagai sumber kekuatan, tantangan dan peluang menuju pribadi yang lebih kuat. Berdasarkan pemahaman inilah strategi pencegahan akan dilaksanakan.

\section{Kewirausahaan Sosial}

Bagaimana sebenarnya kewirausahaan sosial mewarnai usaha-usaha pengentasan masalah sosial? Usaha untuk menjawab pertanyaan ini akan dimulai dari penjelasan mengenai kewirausahaan sosial itu sendiri. Kewirausahaan sosial, secara sederhana merupakan perpaduan antara aktivitas bisnis untuk menghasilkan uang dan aktivitas untuk tujuan manfaat sosial. Pemikiran kewirausahaan sosial di Indonesia (maupun di belahan dunia lainnya), berangkat dari pemahaman baru bahwa sangat sulit sebuah aktivitas sosial dapat bertahan lama tanpa adanya kesinambungan dana operasional. Oleh karena itu, muncullah pemikiran bahwa bukanlah suatu aib menggabungkan aktivitas bisnis dengan aktivitas sosial. Dan bukanlah suatu keniscayaan bagi sebuah lembaga swadaya masyarakat atau organisasi sosial melakukan aktivitas bisnis. Di sisi lain, bukan juga sebuah keanehan jika sebuah institusi bisnis melakukan aktivitas sosial. Berdasarkan kerangka ini, maka 
penulis akan mencoba menggunakannya pada kasus peningkatan pendidikan dan pemenuhan kebutuhan anak-anak terminal stasiun Bandung. Berikut ini adalah beberapa prasyarat yang dapat dikemukakan:

(a) Anak dipandang sebagai individu yang punya potensi untuk dapat bertumbuh kembang secara optimal, memiliki kapasitas ke-berfungsi-an sosial yang positif serta mampu memecah masalah mereka sendiri.

(b) Anak-anak terminal dan keluarganya mampu mengembangkan kapasitas dan potensi mereka sampai batas yang tidak diketahui (unlimited), sama seperti keluarga-keluarga lain.

(c) Inti utama dari semua aktivitas adalah mengurangi kemungkinan anak-anak yang biasa bermain di terminal terjerumus dalam hal-hal negatif atau tergolong dalam kategori anak rentan.

(d) Karena sebagian besar keluarga-keluarga mereka tergolong kategori keluarga miskin, maka program apapun yang akan dilaksanakan harus menyentuh sisi peningkatan ekonomi.

Selanjutnya, berangkat dari poin-poin di atas, maka akan coba disusun sebuah model yang tidak hanya berbasis pendekatan kekuatan namun juga kewirausahaan sosial.

\section{Konsep Dasar Kewirausahaan Sosial}

Kewirausahaan sosial adalah sebuah konsep yang baru dikenal luas oleh dunia pendidikan sekitar lima belas tahun belakangan. Kepopulerannya semakin berkembang ketika Muhamad Yunus dari Bangladesh menerima penghargaan Nobel Perdamaian sebagai seorang wirausaha sosial. Kewirausahaan sosial seperti tersirat dalam terminologinya adalah merupakan sebuah konsep yang sangat luas cakupannya.

The concept of social entrepreneurship (SE) is, in practice, recognized as encompassing a wide range of activities: enterprising individuals devoted to making a difference; social purpose business ventures dedicated to adding for profit motivations to the nonprofit sector; new types of philanthropists supporting venture capital-like 'investment'portfolios; and nonprofit organizations that are reinventing themselves by drawing on lessons learned from the business world (Johanna Mair, Jeffrey Robinson and Kai Hockers, 2006: 1)

Mengacu pada pemaparan di muka, terlihat jelas bahwa cakupan dari terminologi kewirausahaan sosial sangat luas, mulai dari gerakan seorang individu yang mencoba membuat perbedaan sampai ke aktivitas dari organisasi non-profit yang mewirausahakan dirinya dengan mengambil pelajaran dari dunia bisnis. Berikut adalah beberapa definisi tentang social entrepreneurship seperti yang dikumpulkan oleh Mair (Ibid, Mair dkk, 2006: 4).

\begin{tabular}{|c|l|}
\hline Austin & $\begin{array}{l}\text { Social entrepreneurship is innovative, social value creating activity that } \\
\text { can occur within or across the nonprofit, business and public sectors }\end{array}$ \\
\hline \multirow{3}{*}{ Cho } & $\begin{array}{l}\text {.. a quite general working definition of social entrepreneurship; a set } \\
\text { of institutional practices combining the pursuit of financial objectives } \\
\text { with the pursuit and promotion of substantive and terminal values }\end{array}$ \\
\hline
\end{tabular}




\begin{tabular}{|l|l|}
\hline Mair/Noboa & $\begin{array}{l}\text {..we define social entrepreneurship as the innovative use of resource } \\
\text { combinations to pursue opportunities aiming at the creation of } \\
\text { organizations and/or practices that yield and sustain social benefits }\end{array}$ \\
\hline
\end{tabular}

Ketiga definisi tersebut memiliki garis merah yang sama yaitu bahwa kewirausahaan sosial adalah sebuah tindakan kreatif, menggunakan sumber daya yang tersedia untuk menghasilkan manfaat sosial. Selain itu, konsep kewirausahaan sosial juga didefinisikan menurut lingkup kegiatannya yang meliputi usaha non-profit sampai ke wilayah sektor publik.

Social entrepreneurship is innovative, social value creating activity that can occur within or across the non profit, business, and public sector (Austin, Stevenson and Wei-Skillern, 2006)

Unsur utama dari definisi di muka adalah inovasi. Kewirausahaan dinyatakan sebagai sebuah proses kreatif yang menghasilkan kesempatan untuk memproduksi sesuatu yang baru. Sedangkan aspek kedua, yang membedakannya dengan kewirausahaan 'biasa' adalah social value creation. Walaupun keduanya bisa saja bermotif sosial, namun pada kewirausahaan sosial, misi sosialnya dinyatakan dengan sangat jelas dan menjadi daya dorong utama untuk pelaksanaan aktivitas-aktivitasnya.

\section{Perusahaan/Institusi Sosial}

Gerakan kewirausahaan sosial, secara umum dimulai terlebih dahulu oleh tindakan atau aktivitas individu. Namun, pada perjalanannya, setelah kegiatan tersebut semakin membesar lingkup maupun dinamikanya, maka akan dibutuhkan sebuah insitusi untuk menjadi payungnya. Payung yang menaungi kegiatan kewirausahaan sosial inilah kemudian yang lazim disebut sebagai social enteprise. Hal ini sangat diperlukan untuk membedakannya dengan perusahaan/organisasi 'biasa' yang memang murni bergerak dengan tujuan mendapatkan untung sebesar-besarnya (business enterprise).

Menurut Pepin, "A social enterprise is an organisation which is involved in enterprising activities for social aims, with social ownership and democratic principals at its core" (Peppin, 2009: 3). Berdasarkan definisi ini, maka dapat dikatakan bahwa social enterprise adalah sebuah lembaga yang bergerak dengan tujuan sosial namun dalam operasionalnya menggunakan prinsip dan aplikasi bisnis. Di samping itu, social enterprise dapat dinyatakan berdiri di atas dua kaki, yaitu kaki bisnis dan kaki sosial. Kedua kakit ini bergerak seirama untuk mempertahankan kelangsungan organisasi dan juga konsistensi tujuan/misi sosial yang diembannya.

Pertanyaan yang muncul selanjutnya adalah mengapa wirausaha sosial dan mengapa bukan wirausaha biasa? Ini menjadi sebuah kajian menarik mengingat terdapat karakteristik yang berbeda antara kewirausahaan sosial dengan kewirausahaan bisnis/biasa. Salah satu perbedaan utamanya adalah bahwa wadah kegiatan dari kewirausahaan dikenal dengan perusahaan bisnis (corporate enterprise) sedangkan wadah dari kewirausahaan sosial dikenal dengan perusahaan sosial (social enterprise). Berikut ini adalah perbedaan antara perusahaan bisnis (corporate enterprise) dengan perusahaan sosial (social enterprise): 
Tabel 1.1

Perbandingan Perusahaan Bisnis dan Perusahaan Sosial

\begin{tabular}{|c|c|c|}
\hline Perusahaan Sosial & Perusahaan Bisnis & Keduanya \\
\hline $\begin{array}{l}\text { - } \text { Terikat pada komunitas } \\
\text { atau penerima manfaat } \\
\text { tertentu } \\
\text { - Memiliki nilai altruistik } \\
\text { - Fokus dengan } \\
\text { pemberdayaan anggotanya }\end{array}$ & $\begin{array}{l}\text { - Tidak khawatir dengan } \\
\text { dampak sosial } \\
\text { - Menumbuhkan } \\
\text { kesejahteraan dari } \\
\text { para pendiri lembaga/ } \\
\text { perusahaan }\end{array}$ & $\begin{array}{l}\text { - Berusaha mendapatkan } \\
\text { profit dari aktivitas } \\
\text { yang dilakukan } \\
\text { - Terbuka dan akuntabel } \\
\text { - Inovatif }\end{array}$ \\
\hline $\begin{array}{ll}\text { - } & \text { Menggunakan dan } \\
\text { mengembangkan relawan } \\
\text { - } \text { Menawarkan kepemilikan } \\
\text { lembaga oleh karyawan } \\
\text { - } \text { Menciptakan } \\
\text { kesejahteraan sosial } \\
\text { - Memutar seluruh } \\
\text { keuntungan dalam } \\
\text { aktivitas operasional } \\
\text { - } \text { Didorong oleh tujuan } \\
\text { menangani masalah sosial }\end{array}$ & $\begin{array}{l}\text { - Membagi deviden hanya } \\
\text { bagi para pemegang saham }\end{array}$ & $\begin{array}{l}\text { - } \text { Mengambil resiko } \\
\text { - Memiliki standar etik } \\
\text { - Memiliki semangat } \\
\text { memecahkan masalah } \\
\text { - } \text { Komitmen pada } \\
\text { tujuan-tujuan } \\
\text { lingkungan atau sosial }\end{array}$ \\
\hline
\end{tabular}

Berdasarkan tabel tersebut, tampak sejumlah perbedaan mendasar antara perusahaan sosial (social enterprise) dengan perusahaan bisnis (business/corporate enterprise). Satu yang cukup mencolok adalah bahwa pada perusahaan sosial (social enterprise) terdapat keterikatan yang cukup kuat dengan komunitas atau masyarakat tertentu. Artinya, lembaga/institusi ini menyerahkan salah satu daya dukung operasional lembaganya pada kepercayaan mereka terhadap anggota/komunitas di mana lembaga tersebut berada. Hal ini menjadi menarik mengingat karakteristik sebuah komunitas bisa sangat berbeda di lokasi yang berbeda. Belum lagi faktor budaya, kepentingan, norma-norma dan nilai yang dianut. Berikut ini akan diungkapkan rencana pengembangan social enterprise yang bertujuan sebagai upaya pencegahan anak-anak terminal terjerumus ke dalam kondisi negatif.

\begin{tabular}{|l|l|}
\hline $\begin{array}{l}\text { Rencana Aktivitas pengembangan } \\
\text { pendidikan dan karakter anak }\end{array}$ & $\begin{array}{l}\text { Rencana Aktivitas pengembangan bisnis dan } \\
\text { kewirausahaan untuk menunjang pendanaan } \\
\text { bagi aktivitas pengembangan pendidikan } \\
\text { dan karakter anak. }\end{array}$ \\
\hline $\begin{array}{l}\text { A. Pendidikan Bahasa Inggris } \\
\text { Mengingat stasiun dan terminal merupakan } \\
\text { pusat pertemuan arus transportasi dari } \\
\text { berbagai daerah, dan wilayah tersebut } \\
\text { mulai menjadi wilayah internasional, maka } \\
\text { kemampuan bahasa Inggris menjadi sesuatu }\end{array}$ & $\begin{array}{l}\text { A. Usaha Penyewaan taman } \\
\text { Sejak tahun 2008, Pak Ana telah memulai } \\
\text { menghijaukan lahan terminal dengan } \\
\text { berbagai pot tanaman. Saat ini, telah } \\
\text { terdapat hampir ratusan tanaman beraneka } \\
\text { rupa. Oleh karena itu, }\end{array}$ \\
\hline
\end{tabular}




\begin{tabular}{|c|c|}
\hline $\begin{array}{l}\text { yang vital bagi program pengembangan ini. } \\
\text { Tujuan: Mendorong anak-anak terminal } \\
\text { agar mampu menjadi guide bagi } \\
\text { wisatawan, terutama yang akan berbelanja } \\
\text { atau berjalan-jalan di sekitar stasiun. } \\
\text { B. Pendidikan Agama } \\
\text { Agama merupakan tuntunan hidup yang } \\
\text { harus dipatuhi seluruh umat beragama. } \\
\text { Oleh karena itu, pemahaman agama } \\
\text { menjadi sangat penting mengingat ini akan } \\
\text { menjadi tembok atau pagar moral bagi } \\
\text { anak-anak terminal. } \\
\text { Tujuan: diharapkan, melalui pemahaman } \\
\text { agama yang baik dapat mencegah anak- } \\
\text { anak yang tinggal di daerah tersebut } \\
\text { terjerumus ke dalam dunia hitam (baik } \\
\text { premanisme maupun pelacuran). Oleh } \\
\text { sebab itu, pendidikan agama menjadi } \\
\text { bagian penting yang perlu diperhatikan. } \\
\text { C. Rumah Baca } \\
\text { Salah satu sumber peningkatan wawasan } \\
\text { adalah membaca. Dengan membuat } \\
\text { tumah baca yang bersih dan rapi di tengah } \\
\text { terminal yang hiruk pikuk dan cenderung } \\
\text { kumuh, diharapkan dapat membawa } \\
\text { pengaruh positif bagi lingkungan sekitar. }\end{array}$ & $\begin{array}{l}\text { direncanakan taman ini akan disewakan } \\
\text { untuk kepentingan dekorasi. } \\
\text { B. Terapi Ikan } \\
\text { Lokasi di atas halte terminal, } \\
\text { memungkinkan untuk dimodifikasi sebagai } \\
\text { ruang untuk terapi ikan. Lingkungan yang } \\
\text { terbentuk karena arsitektur bangunan serta } \\
\text { lokasi yang strategis, memungkinkan } \\
\text { tempat tersebut menjadi lokasi terapi ikan } \\
\text { yang diminati baik oleh wisatawan lokal } \\
\text { maupun mancanegara. } \\
\text { C.Pengembangbiakan Ikan Koi } \\
\text { Saat ini, di lokasi atas terminal telah mulai } \\
\text { dilakukan pengembangan ikan koi } \\
\text { D. Jasa penitipan barang } \\
\text { Di sekitar terminal, terdapat pasar } \\
\text { baru yang merupakan destinasi belanja } \\
\text { pengusaha Malaysia. Seringkali, ketika } \\
\text { jatah waktu di hotel habis, mereka } \\
\text { membawa tas mereka. Oleh karena itu, jasa } \\
\text { ini dianggap tepat untuk membantu mereka } \\
\text { menunggu waktu penerbangan pulang ke } \\
\text { Malaysia. }\end{array}$ \\
\hline
\end{tabular}

Diharapkan, melalui pendekatan berbasis kekuatan dan pendekatan kewirausahaan sosial, dapat dibangun sebuah social Enterprise based community. Melalui pola ini, diharapkan usaha-usaha untuk mengatasi permasalahan sosial dapat menjadi lebih berkelanjutan dan tingkat keterlibatan masyarakat serta rasa memiliki mereka menjadi lebih tinggi.

Strategi di muka, tentu saja bukan satu-satunya jalan. Namun demikian, upaya yang telah dirintis oleh Bapak Ana, tentu saja layak mendapatkan dukungan. Seorang social worker, sudah selayaknya berpikir luas dan terbuka, sehingga dapat menawarkan bantuan dari berbagai dimensi dan aspek. Sehingga pada gilirannya, akan semakin banyak anggota masyarakat yang menerima manfaat dari kiprah pekerja sosial.

\section{Penutup}

Kekerasan sosial sebagai isu yang dekat dengan kehidupan kita sehari-hari, tentu merupakan hal yang perlu diwaspadai mengingat potensinya untuk menjadikan generasi muda (anak-anak) sebagai korban ataupun pelaku dari kekerasan sosial itu sendiri. Oleh 
karena itu, perlu selalu dipikirkan dan didiskusikan berbagai pola dan skema penanganannya. Model kewirausahaan sosial berbasis pendekatan kesejahteraan ini tentunya belum sempurna, namun paling tidak diharapkan dapat memperkaya khazanah keilmuan kesejahteraan sosial pada umumnya dan strategi penanganan kekerasan sosial pada khususnya. 


\section{Bibliografi}

Afiyah, Noor, Analisis karakteristik sosial ekonomi penduduk di pemukiman sekitar pasar dan terminal Pecangaan Kecamatan Pecangaan Kabupaten Jepara tahun 2005 (Studi kasus di desa Pecangaan Kulon Desa Pecangaan Wetan dan Desa Pulodarat Kecamatan Pecangaan), diunduh dari Web: digilib.uns.ac.id, Surakarta-FKIP. 2006.

Budhi Wibawa, dkk. Dasar-dasar Pekerjaan Sosial. Bandung: Penerbit Widya Padjajdaran, 2010.

Mair, Johanna, Jeffrey Robinson and Kai Hockers, Social Entrepreneurship. New York: PalGrave Macmillan, 2006.

Poulin, John. Strength-Based Generalist Practice: A Collaborative Approach. Cole: Thompson Brooke, 2005.

Pepin, John, Soutcombe Cliff \& Anugerah Fajar, Corporate Social Responsibility and Social Enterprise, A UK and Indonesian Perspective. British Council \& JPA Europe Limited, 2009.

Suyanto, Bagong, Masalah Sosial Anak. Jakarta: Kencana Prenada Media Group, 2010.

Ralph Dolgoff \& Donald Feldstein, Understanding Social Welfare. USA: Pearson Education, Inc, 2003.

Tadjoeddin, M. Zoelfian, Anatomi Kekerasan Sosial dalam Konteks Transisi dalam Working Paper untuk United Nation Support Fasility for Indonesian Recovery, Jakarta: tnp, 2001. 